\title{
Effects of Replacement of Fish Oil by a Mixture of Balanites aegyptiaca and Adansonia digitata Seed Oils on the Growth and Survival of Clarias anguillaris Fries (Linnaeus, 1758)
}

\author{
Mariama Sagne \\ University Institute of Fisheries and Aquaculture (IUPA), Cheikh Anta Diop University \\ (UCAD), 45784, Dakar, Senegal \\ Jean Fall (Corresponding Author)
}

University Institute of Fisheries and Aquaculture (IUPA), Cheikh Anta Diop University (UCAD), 45784, Dakar, Senegal. E-mail: kagoshima77@yahoo.com

Abdoulaye Loum

University Institute of Fisheries and Aquaculture (IUPA), Cheikh Anta Diop University (UCAD), 45784, Dakar, Senegal

Pathe Karim Djiba

University Institute of Fisheries and Aquaculture (IUPA), Cheikh Anta Diop University (UCAD), 45784, Dakar, Senegal

\section{Diégane Ndong}

Direction des Ressources Animales et Halieutiques, Département de l'Agriculture, des Ressources en Eau et de l'Environnement, Commission de l'UEMOA, 380 Av. Pr. Joseph KI-ZERBO, 01 BP 543 Ouagadougou 01-Burkina Faso

Malick Diouf

University Institute of Fisheries and Aquaculture (IUPA), Cheikh Anta Diop University (UCAD), 45784, Dakar, Senegal

Received: Sep. 24, 2018 Accepted: Oct. 16, $2018 \quad$ Published: Mar. 18, 2019

doi:10.5296/jas.v7i1.14521 URL: https://doi.org/10.5296/jas.v7i1.14521 


\section{Abstract}

To investigate the effects of replacement of fish oil by a mixture of Balanites aegyptiaca and Adansonia digitata seed oils three isonitrogenous (35.36\%) and isoenergetic diets (3.48 MJ / $\mathrm{kg}$ ) were formulated for one kilogram $(1 \mathrm{~kg})$. The study was carried out on fries Clarias anguillaris for six weeks.

At the beginning of the experiment, 90 Clarias anguillaris of the initial average weight of $0.82 \pm 0.055 \mathrm{~g}$ were randomly divided into three different groups with two replicates containing 15 fish/each. Fish were kept in six plastic tanks $(50 \times 40 \times 30 \mathrm{~cm})$ container $(50 \mathrm{~L})$. The results showed that the substitution of fish oil by a mixture of Balanites aegyptiaca seed oil and Adansonia digitata seed oil gives growth for all diets. However, the best growths are obtained from all points of view (MWGr, MWGa and SGR) with diet A (mixture of Adansonia seed oil and Balanites seed oil at a ratio of $20: 20$ ) followed by the diet D (mixture of Adansonia seed oil and Balanites seed oil at $10: 30$ ) compare to the control diet M containing fish oil. The best FCR was observed with the diet A followed by the diet D compare to the FCR observed with the diet M. The PER was higher in diet A (0.57) followed by diet $\mathrm{D}$ with $(0.45)$ that has no significant difference with the control diet $\mathrm{M}(0.43)$. The highest value $63 \%$ was obtained with the diet $\mathrm{D}$ followed by $60 \%$ with the diet $\mathrm{M}$ and finally the lowest value 53\% was obtained with the diet A. In regards to the growth performance, fish fed a $100 \%$ vegetable oil diet showed the best growth performance. Therefore, the replacement of fish oil with a mixture of Balanites aegyptiaca seed oil and Adansonia digitata seed oil has no negative impact on the growth of Clarias anguillaris fry. It would be interesting first to study the inclusion rate of Balanites aegyptiaca seed oil for a partial replacement of fish oil.

Keywords: mixture, Balanites aegyptiaca seed oil, Adansonia digitata seed oil, growth, Clarias anguillaris, fry

\section{Introduction}

Global production of aquaculture has increased dramatically in recent years. From a production of 4 million tons in 1980, it rose to 63 million tons in 2011. It grew at an average annual rate of over $8.8 \%$ between 1980 and 2011, compared to $1.2 \%$ for fisheries catches (the production of which has been stagnating at around 90 million tons in recent decades) (FAO, 2012).

Today, $43 \%$ of the fish on the world market comes from aquaculture, while this share was only $9 \%$ in 1980. Aquaculture continues to grow at a faster rate than all other production sectors food of animal origin (FAO, 2012).

This tremendous growth is the result of research and innovation in the control of farming conditions and especially in the feed. However, these spectacular advances in aquaculture are less visible in some parts of the world. It is the case of Senegal, which is a developing country whose aquaculture production has not yet reached a sustainable level. According to (Siddhuraju and Becker, 2003), the major constraint to the emergence of aquaculture in developing countries is the high cost of feed. For them, this is due to the use of animal by-products, such as fishmeal and fish oil, in the feed for aquaculture. According to 


\section{Macrothink Institute ${ }^{\text {TM }}$}

Slembrouck et al., 1991 and Gourene et al., 2002, regarding expenditure, feed accounts for about $50 \%$ of the cost of production of farmed fish.

As a result, the use of plant by-products to lower the cost of feed should be considered, but this requires studies to produce a high-performance, low-cost feed based on available plant products. This is what drives us to research the use of oils such as Balanites aegyptiaca and Adansonia digitata seeds oil to replace fish oil in the diet of Clarias anguillaris.

\section{Material and Methods}

\subsection{Breeding Conditions}

The study was carried out on fry Clarias anguillaris for six weeks. At the beginning of the experiment, 90 Clarias anguillaris fry of the initial average weight of $0.82 \pm 0.055 \mathrm{~g}$ were randomly divided into three different groups with two replicates containing 15 fish/each. Fish were kept in six plastic tanks (50 x $40 \times 30 \mathrm{~cm})$ container $(50 \mathrm{~L})$.

The tanks were cleaned daily in the morning and afternoon by siphoning accumulated waste. About half of the water in each tank was replaced. The fish were fed $10 \%$ of their body weight twice daily (8:00 am and 5:00 pm), then this rate was gradually reduced according to the weighing. The biomass of each tank was weighed at the beginning and every two weeks and the feeding rate was adjusted accordingly.

\subsection{Diets Preparation}

\subsubsection{Diets Formulation}

Three isonitrogenous (35.36\%) and isoenergetic diets (3.48 MJ / kg) were formulated for one kilogram $(1 \mathrm{~kg})$. These diets differ only in their oil composition (Table 1). Thus the estimation of the biochemical composition of food is recorded in Table 2.

Table 1. Diets composition

\section{Diets (g/kg)}

\begin{tabular}{lccc} 
Ingredients & A & $\mathrm{D}$ & $\mathrm{M}$ \\
\cline { 2 - 4 } Corchorus tridens (binder) & 20 & 20 & 20 \\
Wheat bran meal & 40 & 40 & 40 \\
Peanut cake meal & 220 & 220 & 220 \\
Maize meal & 130 & 130 & 130 \\
Fishmeal & 300 & 300 & 300 \\
Moringa leaves meal & 230 & 230 & 230 \\
Vitamines mix $^{\text {a }}$ & 10 & 10 & 10 \\
Minerals mix & 10 & 10 & 10 \\
Adansonia seed oil & 20 & 10 & 0 \\
Balanites seed oil & 20 & 30 & 0 \\
Fish oil & 0 & 0 & 40 \\
\hline
\end{tabular}

$\mathrm{a}=$ vit A 250000 UI; vit D3 250000UI; vit E 5000mg; vit B1 100mg; vit B2 400mg; vit B3(pp)

1000mg; vit B5 pantode Ca2000mg; vit B6 300mg; vit K3 1000g; vit C 5000mg; H biotin 15mg; choline 100g; anti-oxydant (BHT), crushed and calcined attapulgite qs 1000mg; 
$\mathrm{b}=$ phosphorus $7 \%$; calcium $17 \%$; sodium $1,5 \%$; potassium $4,6 \%$; magnesium $7,5 \%$; manganese 738mg; zinc 3000mg; iron 4000mg; copper 750mg; iodine 5mg; cobalt 208mg; calcined and ground attapulgite qs 1000g; fluorine 1.5\% (approximately),

Table 2. Estimated biochemical composition of the three diets

\begin{tabular}{lc}
\hline Composition & Diets (A, D, M) \\
\hline DM (\%) & 89.75 \\
Ash (\%) & 4.31 \\
Gross energy (MJ/Kg) & 1.80 \\
Digestible energy (MJ/Kg) & 1.68 \\
Protein (\%) & 35.36 \\
Digestible Protein (\%) & 0.14 \\
Lipid (\%) & 11.69 \\
Fiber (\%) & 3.74 \\
\hline
\end{tabular}

\subsubsection{Feed Manufacturing}

For the manufacture of diets, the raw ingredients were crushed, screened to remove certain impurities they contained. Then depending on the formulation they were weighed, mixed until a homogeneous powder was obtained, oil and water were added and then homogenized again. The dough obtained was passed through an extruder to give filaments shaped spaghetti that was dried under the sun for 1 to 2 days before being packaged in jars glass until use.

\subsection{Physicochemical Parameters}

The physicochemical parameters $(\mathrm{pH}$ and temperature) were measured twice daily in the morning and afternoon before feeding throughout the experiment with a multiparameter device.

\subsection{Growth Parameters and Survival Rate}

The growth parameters were described as in the following formulas:

Absolute Mean weight gain (AWGa, (g/ fish)) = final mean body weight - initial mean body weight;

Specific growth rate $(\mathrm{SGR},(\% /$ day $))=((\mathrm{In} \mathrm{Wt}-\mathrm{In} \mathrm{Wi}) / \mathrm{T}) \times 100$, where Wt is the weight of 
fish at time $\mathrm{t}, \mathrm{Wi}$ is the weight of fish at time 0 , and $\mathrm{T}$ is the rearing period in days;

Feed conversion rate $(\mathrm{FCR})=$ total dry feed fed $(\mathrm{g} / \mathrm{fish}) /$ total wet weight gain $\mathrm{g} /$ fish .

Survival rate $(\%)=100 *$ (number of fish which survived/initial number of fish).

Protein efficiency ratio $($ PER $)=$ wet weight gain $(\mathrm{g}) /$ total protein intake $(\mathrm{g})$

\subsection{Statistical Analysis}

The results were subjected to one-way analysis of variance (ANOVA) followed by comparison tests of Duncan. These analysis were performed using the Statistical Analysis System (SAS) software.

\section{Results and Discussion}

\subsection{Results}

\subsubsection{Water Quality Parameters}

The temperature and $\mathrm{pH}$ were recorded daily during the entire experiment to monitor water quality. The mean, minimum and maximum values per treatment are shown in Table 3.

Table 3. Physico-chemical parameters

\begin{tabular}{llll}
\hline & \multicolumn{3}{c}{ Diets } \\
\hline Parameters & $\mathrm{A}$ & $\mathrm{D}$ & $\mathrm{M}$ \\
\hline${\text { Mean } \mathrm{T}^{\circ} \mathrm{C}}^{\circ}$ & 26.02 & 26.11 & 26.3 \\
${\text { Minimum } \mathrm{T}^{\circ} \mathrm{C}}^{\text {Maximum } \mathrm{T}^{\circ} \mathrm{C}}$ & 24.15 & 24.48 & 24.60 \\
Mean pH & 28.25 & 28.33 & 28.40 \\
Minimum $\mathrm{pH}$ & 7.02 & 7.02 & 7.02 \\
Maximum $\mathrm{pH}$ & 7.01 & 7.01 & 7.01 \\
\hline
\end{tabular}

The results obtained show that the temperature varies between 24.15 to $28.60^{\circ} \mathrm{C}$ with an average value of $26^{\circ} \mathrm{C}$ in all treatments (A, D, M).

The $\mathrm{pH}$ during the experiment shows a slight variation from 7.01 to 7.03 with an average of 7.02 found in all diets.

\subsubsection{Growth Performance, Feed Efficiency and Survival}

Data on the absolute mean weight gain (MWGa), relative mean weight gain (MWGr), specific growth rate (SGR) and feed conversion rate (FCR), Protein efficiency ratio (PER) and the survival rate (SR) are shown in Table 4 
Table 4. Growth performance, feed efficiency, and survival

\section{Diets}

\begin{tabular}{llll}
\hline Parameters & A & D & M \\
\hline IMW (g) & 0.05 & 0.05 & 0.05 \\
FMW (g) & $0.14^{\mathrm{a}}$ & $0.12^{\mathrm{a}}$ & $0.11^{\mathrm{a}}$ \\
MWGr (\%) & $148.17^{\mathrm{a}}$ & $111.48^{\mathrm{a}}$ & $96.19^{\mathrm{b}}$ \\
MWGa & $0.08^{\mathrm{a}}$ & $0.06^{\mathrm{a}}$ & $0.05^{\mathrm{a}}$ \\
SGR (\%/d) & $2.09^{\mathrm{a}}$ & $1.78^{\mathrm{a}}$ & $1.60^{\mathrm{a}}$ \\
FCR & $1.73^{\mathrm{a}}$ & $1.85^{\mathrm{a}}$ & $1.91^{\mathrm{a}}$ \\
PER & $0.57^{\mathrm{a}}$ & $0.45^{\mathrm{a}}$ & $0.43^{\mathrm{a}}$ \\
SR (\%) & 53 & 63 & 60 \\
\hline
\end{tabular}

The results showed that the substitution of fish oil by a mixture of Balanites aegyptiaca seed oil and Adansonia digitata seed oil gives growth for all diets. However, the results differ according to the diets. Indeed, overall, the best growths are obtained from all points of view (MWGr, MWGa, and SGR) with diet A (mixture of Adansonia seed oil and Balanites seed oil is equal 20: 20) followed by the diet D (mixture of Adansonia seed oil and Balanites seed oil 10: 30) compare to the control diet M containing fish oil.

Nevertheless, the best FCR was observed with the diet A followed by the diet D compare with the FCR observed with the diet M.

The PER ranged from 0.43 to 0.57 . It is higher with diet A (0.57) followed by diet D with (0.45) that has no significant difference with the control diet $\mathrm{M}(0.43)$.

During the experiment, the survival rate in the different diets varies from $53 \%$ to $63 \%$. The highest value $63 \%$ is obtained with the diet D followed by $60 \%$ with the diet $\mathrm{M}$ and finally the lowest value $53 \%$ is obtained with the $\operatorname{diet} \mathrm{A}$.

\subsection{Discussion}

\subsubsection{Water Quality}

The mean temperature found in the tanks at the end of the experiment varied between 26.02 and $26.30^{\circ} \mathrm{C}$. These values are in agreement with those presented by Akinvole and et Faturoti (2007) for whom the recommended temperature range for raising Clarias alevins and juveniles is between 23 and $26.8^{\circ} \mathrm{C}$. 
Also, the hydrogen potential $(\mathrm{pH})$ values ranged from 7.01 to 7.03 with an average of 7.02 in all treatments. Indeed, these values lie within the optimal growth range of Clarias (6.5 and 9) (Kanangire, 2001).

\subsubsection{Growth Performance, Feed Efficiency and Survival}

This study showed that vegetable oils have considerable potential to replace fish oil in diets for Clarias anguillaris. The results obtained are reasonably acceptable with higher survival and feed efficiency performances with diets containing vegetable oil (baobab oil and balanite oil) compared to the control diet based on fish oil, This observation could imply that there was no problem of palatability and that their uses were adequate, which is similar to the work of Aderolu and Akinremi (2009) in the use of coconut oil and 1 Peanut oil in the diet of catfish. Sotolu (2010) recorded a similar observation when feeding diets containing benni seed oil, peanut oil, soybean oil, and palm oil to fry Clarias gariepinus. This may confirm that the use of vegetable oils in Clarias diets did not have adverse effects on dietary intake, growth, and survival.

Indeed, the highest average weight gain was obtained with diet A containing vegetable oil (a mixture of HB and HA). These results are similar to those of (Sagne et al., 2013) for which the best weight gain was obtained with diet-fed diets containing peanut oil and equal-oil soybean in tilapia.

Concerning SGR, the results obtained show positive growth performances for fish fed with food A, which has a SGR of 2.09 against a SGR of 1.60 for fish fed the control diet. These results are superior to those obtained by Ochang et al. (2007) with results ranging from 0.62 to 0.85 in his study on the replacement of cod liver oil with palm oil in Clarias gariepinus. As well as those obtained by Ikeda et al., (2011) on Pterophyllum scalare anguillaris with SGR ranging from 0.44 to 0.50 .

Also, the best feed conversion rate is obtained by the diet A (equal proportion of baobab oil and balanite oil) with an FCR of 1.73 with respect to the diet M (100\% HP) for an FCR of 1.91. These results corroborate those of Sagne et al., (2013) who obtained the best FCR with diet E (equal proportion of peanut oil and soybean oil) with a FCR of 1.37 versus 1.77 for regime A (100\% HP). However, they are similar to those of Kamarudin et al., (2011) who found FCRs ranging from 1.6 to 1.9 in his study on the effects of the replacement of food fish oil by different sources of food, Vegetable oil on the growth performance and tissue fatty acid profiles of Tor tambroides juveniles.

The PER was not significantly different between the treatments, but is higher with the diet A (a mixture of Balanites oil and baobab oil equals) and lower with the control diet containing fish oil. The improvement in PER could probably be related to the nature of the lipids. On the contrary, Peres and Oliva-Teles (1999) did not observe any protein sparing effect of lipid when they fed European sea bass on graded levels of dietary lipid.

At the end of the experiment, the survival rate recorded shows that we did not have any significant problems related to the food. The percentage of survival obtained between 53 and $63 \%$ is low. These mortalities occur one, two or three days after weighing or as a result of aggressiveness between the fish. 


\section{Conclusion and Perspective}

The objective of this study was to investigate the effects of total replacement of fish oil by a mixture of vegetable oil in the diets for Clarias anguillaris fry on growth and survival.

At the end of this study, satisfactory but preliminary results were obtained. In regards to the growth performance, fish fed a $100 \%$ vegetable oil diet showed the best growth performance compared to a diet containing $100 \%$ fish oil. These results are the same for the food conversion rate (FCR).

We can, therefore, say that the replacement of fish oil with a mixture of Balanites aegyptiaca oil and Adansonia digitata oil has no negative impact on the growth of Clarias anguillaris larvae.

Moreover, to completely get rid of raw materials (flour and oil) of fish origin in the formulation, the current challenge in aquaculture is to study the possibilities of a joint replacement of fishmeal and fish oil by accessible plant by-products to reduce the dependence of the aquaculture industry on species.

The prospects following this study are multiple. It would be interesting first to study the oils separately. However, also to study the inclusion rate of suitable oils for a partial or total replacement of fish oil.

\section{References}

Aderolu, A. Z., \& Akinremi, O. A. (2009). Dietary effects of coconut oil and peanut oil n improving biochemical characteristics of Clarias gariepinus juvenile. Turkish Journal of Fisheries and Aquatic Sciences, 9, 105-110.

Akinvole, A. O., \& Faturoti, E. O. (2007). Biological performance of African Catfish (Clarias gariepinus) cultured in recirculating system in Ibadan. Aquacultural Engineering, 36(1), 18-23. https://doi.org/10.1016/j.aquaeng.2006.05.001

FAO (2012). Situation mondiale de la pêche et l'aquaculture Rome. 241 pp.

Gourène, G., Kobena, K. B., \& Vanga, A. F. (2002). Etude de la rentabilité des fermes piscicoles dans la région du moyen Comoé. Abidjan, Côte d'Ivoire, Université Abobo-Adjamé : Rapport Technique. 41 p.

Ikeda, A. K., Zuanon, J. A. S., Salaro, A. L., Freitas, M. B. D., Pontes, M. D., Souza, L. S., \& Santos, M. V. (2011). Vegetable oil sources in diets for freshwater angelfish (Pterophyllum scalare, Cichlidae): growth and thermal tolerance, Arq. Bras. Med. Vet. Zootec, 63(3), 670-677. https://doi.org/10.1590/S0102-09352011000300019

Kamarudin, M. S., Ramezani-Fard, E., Saad, C. R., \& Harmin, S. A. (2011). Effects of dietary fish oil replacement by various vegetable oils on growth performance, body composition and fatty acid profile of juvenile Malaysian mahseer, Tor Tambroides. Aquacult. Nutr. https://doi.org/10.1590/S0102-09352011000300019

Kanangire, C. K. (2001). Effet de l'alimentation des poissons avec Azolla sur l'écosystème 
agropiscicole au Rwanda. Dissertation présentée en vue de l'obtention du grade de Docteur en Sciences. Facultés universitaires Notre-Dame de la paix, Namur, Belgique. 220p.

Ochang, S. N., Fagbenro, O. A., \& Adebayo, O. T. (2007). Growth Performance, Body Composition, Haematology and Product Quality of the African Catfish (Clarias gariepinus) Fed Diets with Palm Oil. Pakistan Journal of Nutrition, 6(5), 452-459. https://doi.org/10.3923/pjn.2007.452.459

Peres, H., \& Oliva-Teles, A. (1999). Effect of dietary lipid level on growth performance and feed utilization by European sea bass juveniles (Dicentrarchus labrax). Aquaculture, 179(1), 325-334. https://doi.org/10.1016/S0044-8486(99)00168-4

Sagne, M., Loum, A., Fall, J., Ndong, D., Diouf, M., Sarr, A., \& Thiaw, O. (2013). Effects of Different Types of Oils on Growth Performance, Survival and Carcass Composition of Nile Tilapia (Oreochromis niloticus), Journal of Biology and Life Science, 4(2).

Siddhuraju, P., \& Becker, K. (2003). Comparative nutritional evolution of differentially processed mucuna seeds on growth performance, feed utilization and body composition in Nile tilapia (Oreochromis niloticus L.). Aquac. Res., 487-500.

Slembrouck, J., Cisse, A., \& Kerchuen, N. (1991). Etude préliminaire sur l'incorporation de liants dans un aliment composé pour poisson d'élevage en Côte d'Ivoire. J. Ivoir. Océanol. Limnol, CRO, Abidjan. pp. 17-22.

Sotolu, A. O. (2010). Feed utilization and biochemical characteristics of Clarias gariepinus (Burchell, 1822) fingerlings fed a diet containing fish oil and vegetable oil as total replacements. World Journal of Fish and Marine Sciences, 2(2), 93-98.

\section{Copyright Disclaimer}

Copyright for this article is retained by the author(s), with first publication rights granted to the journal.

This is an open-access article distributed under the terms and conditions of the Creative Commons Attribution license (http://creativecommons.org/licenses/by/4.0/). 